\title{
African Identity \& globalization in Music Education approaches The 'African' in the Global Music Education Discourse: Towards identification and implementation
}

\section{Prof. Dr. Emily Akuno*}

\begin{abstract}
Education has been identified as a means and process of socialization. Through information, experiences and interactions, individuals are systematically sensitized and capacitated to live meaningfully under diverse circumstances. The socialization equips learners with intellectual, relational and emotional resources with which to negotiate the process of living.

Music, recognized as the organ of culture, speaks to, for and of a cultural context that is beneficial for the socialization mandate of education. If a product of 'education' is to acquire cultural intelligence (Earley, P.C. and Ang, S. , 2003; Earley, P.C. and Mosakowski, E., 2004) their training would require developing knowledge and skills to enable them operate in contexts of diverse cultures (Ang, S., Van Dyne, L. and Koh, S. K. , 2006). Music education, when fashioned to expose learners to the experience of the music of diverse cultures, is a useful tool in developing culturally grounded and intelligent societies.

As a global phenomenon, music education operates through a context that articulates and defines the concepts and pertinent skills that characterise it. When education socialises, music in the context of education injects a cultural identity into the socialised beings. The cultural attributes of the music knowledge studied are absorbed by learners.

The term 'African' is broadly used to refer to matters that relate to the content and people of African origin. As a tag to music education, it is employed here as an identifier of a context of experiences and relationships from which come knowledge and the skills to use that knowledge.
\end{abstract}

* Professor of Music, the Technical University of Kenya, Nairobi. Past - President of International Music Council. President- Elect International Society of Music Education- ISME.

مجلة علوم وفنون الموسيقى - كلية التربية الموسيقية - المجلد ب؟ - عدد خاص "الموسيقى وهوية الشعوب" - أغسطس ا.r.rه 
This presentation purposes to interrogate the term as employed in music education, specifically focusing on its identity and experience for teaching and learning.

\section{Conceptual Considerations}

The term 'music' in Africa will more often than not refer to a phenomenon whose meaning differs with the context of its manifestation. When understood as participatory (Oehrle, 1993), it involves human beings in shared experiences. As a communal activity, it requires various participants taking up a variety of roles for its success. As an agent of socialisation, it covers a multitude of functions in society, covering life's 'crises' (Nketia, 1992) and accompanying the individual 'from the cradle to the grave' (Zake, 1986).

With such an understanding of music, music education goes a step further than teaching the 'how tos' of sound production. It ends up being the process of gaining meaning through the experience of music. It becomes an endeavour to make something out of sound stimuli, something that leads one to participate effectively in communal events. This calls for the assimilation of concepts and honing of skills that enable one to make use of the concepts. It requires the acquisition of a vocabulary of experiences (prior knowledge) to ground meaningful engagment with new information.

The three mode view of music (Akuno E. A., 2016) facilitates an interrogation of the phenomenon that captures its role in the life, expressions and reflections of a vast majority of contemporary Africa's communities. Music is first and foremost a concept. It is an idea, mental impressions that exist in the composer's mind. It is however conceived of as sound. Second, when the idea is given substance, music is created in a format that can be shared with others. As a work of art, music is an object that has a start and end, with aesthetic properties that appeal to an audience. Yet, third, when performed, it is part of a socio-cultural activity whose substance both gives the music an identity, and relies on the music for its value. It is therefore an event in which people participate in ways that spell out their roles and give them tasks towards the development of leadership and decision-making.

The content of music which is designated African is identifiable, like in the music from other regions, from its distinctive structures, timbres, tonal and temporal elements. The elemental theory of music (Akuno, 2016) defines music as a body of

مجلة علوم وفنون الموسيقى - كلية التربية الموسيقية - المجلد ب؟ - عدد خاص "الموسيقى وهوية الشعوب" - أغسطس ا.r.rم 
sounds with tonal and temporal elements. Whereas the theory defines music in its very basic elements of pitch and time, leading to intervals and rhythm (Akuno E. A., 2016), the expressive and qualitative elements are important considerations in identifying music's origin and character. They speak of the resources and modes of music making. These are often culture-oriented, and are hence means of identifying musical works of art by region of origin, as well as function.

Identification

A simple definition of the term 'African' denotes the usage of the word to refer to something done or made in Africa, with African resources or by an African. Music as a cultural phenomenon fits in all the three categories of the definition, and lends itself to the education dialogue as a valuable ingredient for artistic and cultural sensitisation and development.

In Africa

History is replete with data showing the influx of visitors to Africa. They came for various reasons and all had an impact on culture and its expressions as practised by the people they encountered. The African soundscape has transformed systematically as a result of the marriage of the sounds of the settling visitors and those of the welcoming hosts. Be it through acculturation or syncretism, new sounds coming into the environment have caused a disruption. The tension created by this new information coming into the space of old experiences, in the form of intervals and rhythms, has been creatively resolved through various types of adaptation, where creativity is the way out of the culture-information conflict (Akuno E. A., 2016).

Whereas some of this took place over time, so that the metamorphosis lead to new art forms almost unconsciously, there are instances where there were deliberate, conscious moves to incorporate elements of non-African idioms into the musical expressions. These resulted in, among others, art music. In this category are choral pieces in SATB taught to choirs, which are part of another civilisation, and whose principles are now used extensively in Africa. Similarly, there are various fusion styles in the popular music genres that adopted some inflections, idioms and instruments. These include Taarab and chakacha that fuse heavily Arabic music

مجلة علوم وفنون الموسيقى - كلية التربية الموسيقية - المجلد ب؟ - عدد خاص "الموسيقى وهوية الشعوب" - أغسطس اب.rم 
styles with local dialects and their characteristic tonal and rhythmic inflections. These are practised predominantly along the East African coastal strip.

Despite containing sonic and material resources of external extraction, these 'new' genres are components of African music by virtue of their application in Africa. In instances of hybridised forms, their 'Africa-ness' is more significant because of the presence of the purely African elements embedded in the created art works and forms. Some of these elements include design, melodic and rhythmic structures and nuances.

When a piece of music qualifies to be 'African' through this pathway (made in Africa), it remains African despite the context of its performance henceforth. A lot of assimilation happens when cultural expressions co-exist. These are discernible in the elements that constitute the works of art (form, rhythm, interval, language), in the process ingrained in these works (performance, composition) as well as the practices that incorporate the works (socio-cultural contexts of music-making).

The context of music making in Africa, as elsewhere, feeds its content, seen as both the work of art and its processes. With a dual role to play, ritual and recreational, music finds space in all of life's activities. As a functional object, it shapes the experience of socio-cultural events, be they of a ritual or recreational nature. When thus event-driven, music's makers take roles in the music that tally with the roles they play in the event - leader vs lead, active vs passive participant etc. Similarly, the design of the music lends itself to performance by participating entities, and hence the popularity of call-and-response in its diversity (short calllong response; long call-short response ; long call-long response).

With African Resources

Materials of music contribute to its character. The material are both objects/contraptions/artefacts and sonic concepts and images. The former are the instruments that create the music. The latter are the thematic resources, both music and cultural. The melorhythmic nuances that lend the music its shape and character depict the manner in which musical material (resources) are harnessed to create a work with a definite identity. For much of Africa, especially those communities with song traditions, these nuances reflect the spoken language. The 5 major language families of Africa have distinct characteristics that influence songs. The

مجلة علوم وفنون الموسيقى - كلية التربية الموسيقية - المجلل ب؟ - عدد خاص "الموسيقى وهوية الشعوب" - أغسطس ا.r.rم 
lyrics, especially of songs in tonal languages, influence the melodic contours and rhythmic organisation of songs. The accentuation (rhythmic stress) and intonation (pitch relations) of the syllables in a word demand observance in songs, assisting with cultural authentication and acceptance. This further contributes to the validation of works of art due to the degree of compliance with reflection of these basic temporal and tonal principles in music. There were instances when I heard Luo music in Kiswahili language - i.e. the rhythm and melody were characteristically Luo, lending themselves to the Luo language, while the lyrics were in Kiswahili, a language that operates on a different set of rules.

The artefacts (music instruments) are made from material found in the makerplayers' environment. Their distinctive buzz, whirr, purr, rumble, whistle etc speak to and of a performance context whose atmosphere they help build. The timbre is such a significant contributor to the aesthetic moment that care is often taken in selecting material for making idiophones, membranophones, chordophones and aerophones used in both ritual and entertainment music events. With the context determining the content of music, the reason for performance guides the choice of artefacts employed in music making.

By an African

This may be controversial. Who IS an African? Or, when does an individual qualify to be an African? From a cultural perspective, I'll refer to an African as an individual with current or past ties to the content of Africa through ancestry. This term is a tag that denotes ancestry in a geographic space.

However, it also speaks to cultural characteristics, grounded on world view that determines not only what people do, but also how they do it. The African can therefore be an individual with certain behavioural and belief characteristics that are common to the inhabitants of Africa.

The belief system, that which colours our view of the world and its happenings, shapes our expressions and reflections of each day's events, our relationships and our aspirations. These are characteristically the content and contexts of our music. They are ultimately characteristics of our 'culture' - both the cultural heritage and our daily ways of doing things.

مجلة علوم وفنون الموسيقى - كلية التربية الموسيقية - المجلل ب؟ - عدد خاص "الموسيقى وهوية الشعوب" - أغسطس ا.r.rم 
So a song created by an individual with a certain world view, to express his/her perception and conception of that world, presents a good picture of that individual's world, and hence music being an organ of culture. The music by an African speaks to the world characterised as 'Africa'.

Implementation

Mbuta chielore gi moye - The Nile perch fries itself in its own oil/fat.

$$
\text { (Luo saying) }
$$

The saying above speak to self-sufficiency. There are processes in (African) musical works that denote how they are to be applied. An analysis of the basic structures reveal (inter)relationships that present elements, roles and strategies that characterise the music. Music in life is both performed and learned, In both situations, it is a context of learning and training.

Performance

The elements of music relate in ways that spell out structures and designs. In performance, it is often evident where there is a lead or the theme holder from a sonic perspective. Visually, the formations and movements support, augment and/or reveal these relationships. In both ritual and entertainment forms, leadership roles are significant, because they enable the ritual or entertainment function to progress and crystallise.

Performance, in reflecting the context and content of music, involves people in diverse roles that complement each other. As a participatory event, music performance celebrates societal relationships and roles in significant ways. It allows for temporary (to more or less degrees) affiliations, contests, support etc. It is space for selection, enhancement, negotiation and celebration of components of the whole. The relationships negotiated are between the elements, ingredients, resources that create the whole. Parts, instrument vs voice, and song-instrumentdance relationships, etc. attest to society's ways of testing, collaborating, regenerating, reinforcing, selecting, propagating etc. They contribute to the cycle that life is, and the relevant changes that ensure continuity of human existence in the various cultural situations.

In performance, music is the Nile perch that fries itself in its own oil. Whereas it is self-contained with respect to the oil, there is need for an external catalyst that

مجلة علوم وفنون الموسيقى - كلية التربية الموسيقية - المجلا ب؟ - عدد خاص "الموسيقى وهوية الشعوب" - أغسطس ا.r.rم 
allows the frying to happen - the heat. This melts, extracts the oil to allow for frying. Similarly, the context (event) of the performance allows for the selection (extracting the oil) and application of the relevant resources to facilitate the musicmaking. These contexts are primarily the 'crises of life' from the 'cradle to the grave', the events that characterise and facilitate human existence, hence birth, naming, initiation, work, courtship, marriage, death etc and the music will be for both recreational and ritual purposes.

Teaching and Learning

In and out of the classroom, music is a tool for learning of various sorts, the least contested being aesthetics. This happens through the training of senses to gain meaning in the presence of a music stimulus (Akuno, 2016). The skills and knowledge that propel this are acquired in what is largely labelled 'music education'.

There are contexts where educators feel that they do not engage in 'music education' because what they do is 'just singing' (Akuno E. A., Perceptions and Reflections of Music Teacher Education In Kenya, 2012). Hence the concept of music teaching and learning is not universally agreed upon, but dependent on teachers'/educators' notions and convictions. 'the case cited above had a socialisation that understood music education as the teaching and learning of (western) music theory and literacy. This was the result of a heavily theoretical and content-oriented music learning programme, a space that excluded 'African' music's participatory nature.

In teaching and learning, the Nile perch can and must 'fry itself in its own oil'. The processes of music mentioned above are a key to how to negotiate it in learning and teaching as they are for performance. Some of these processes lend themselves to a pedagogy that sustains and obeys relationships underscored by these processes.

The common example of participatory procedures emanates from the call-andresponse structure, a format of music presentation that allows the 'audience' to be performers. The variants of this form allow for quick mastery of music concepts (theory, contexts) and skills (manipulative, literacy) because leaners either copy the model, respond minimally to the teacher's call or (finally) pick up the

مجلة علوم وفنون الموسيقى - كلية التربية الموسيقية - المجلا ب؟ - عدد خاص "الموسيقى وهوية الشعوب" - أغسطس ا.r.rم 
(minimal) cues from the teacher to launch into their won productivity. These denote steps and stages in the creativity development, and scope for articulating processes and resources that are African.

The hallmark of participatory pedagogy will be:

A practical learning procedure where learners develop skills and appreciate concepts of music by behaving musically

Like espoused by Kodály, the highest quality music material is employed for teaching. This ensures learners are exposed to society's/the community's concepts of aesthetics, fine art and appropriate performance practice;

A skilled model who will inspire learners while passing down society's values in and through music, including high esteem for the discipline.

Through its content and context, historical, economic and philosophical information is gathered. Music is therefore space for social, cultural, economic, philosophical and psychological training and learning through which individuals may develop cultural intelligence. Indeed, much of Africa's (oral) history is narrated in songs by court musicians and other classical music performers and composers.

Conclusions

This presentation set out to articulate ways of discerning and applying the African cultural ingredients in music education. This is to be achieved through identification of characteristic features of African music, with the understanding that these are not static, but shift with the dynamics of the culture that embraces the music.

As an organ of culture, music bears the culture on its wings, delivers it to diverse audiences and enables it to acquire an identity based on and commensurate with the context of its performance. As a body of knowledge, it contains information in the form of content (concepts) and processes (procedures) that provide resources for teaching and learning.

The African identity is a broad, multidimensional concept found in diverse types of music because 'African' is not confined to a geographic space. It is global because of the dispersion of populations in whom cultural blueprints are ingrained. They

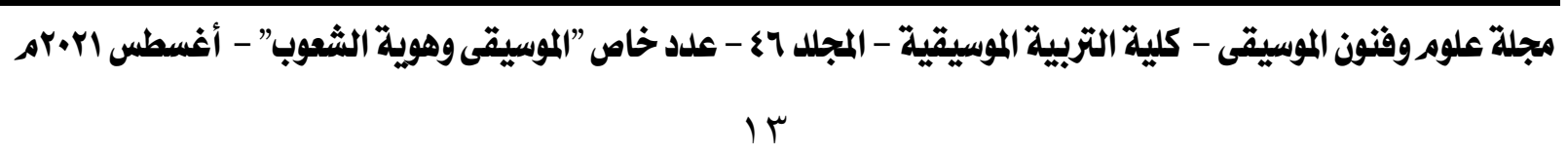


produce these in their cultural expressions, hence jazz, gospel, spirituals, etc that are as African as they are South and North American.

The participatory approach that speaks to learning by doing was described by New in 1971 (see Akuno, 2016) as what Africa had been doing for centuries that the West was trying to learn. Africa's academy is recently trying to recapture this after losing it with the introduction of a Eurocentric music education.

Africa's success with making music education African lies in utilising her resources that lend themselves to practical experience as the way to learn (Akuno E. A., 2015). A study of these resources yield concepts and procedures for developing musicianship and music skills that are applicable in diverse contexts, while grounding the learner in their cultural musical sounds and idioms. This kind of exposure enriches the learners' vocabulary of music experiences, knowledge and skills thereby increasing their global and local relevance. 
Works Cited

Akuno, E. A. (2012). Perceptions and Reflections of Music Teacher Education In Kenya. International Journal of Music Education, 30, 272-291.

Akuno, E. A. (2015). The Singing Teacher's Role in Educating Children's Abilities, Sensibilities and Sensitivities. British Journal of Music Education , 32(3), 299-313. doi:10.1017/S0265051715000364

Akuno, E. A. (2016). Issues in Music Education in Kenya (2nd ed.). Nairobi: Emak Music Services.

Ang, S., Van Dyne, L. and Koh, S. K. . (2006). 'Personality Correlates of the fourfactor model of cultural intelligence. . Group and Organisation Management, 31, 100-123.

Earley, P.C. and Ang, S. . (2003). Intelligence in Recent Public Literature. . Stanford: Stanford University Press.

Earley, P.C. and Mosakowski, E. (2004). Cultural Intelligence. . Harvard Business Review , 82(10), 139-146.

Nketia, J. K. (1992). The Music of Africa . London: Gollancz.

Oehrle, E. (1993). Education through Music: Towards a South African approach. . British Journal of Music Education, 10(3), 255-261.

Zake, G. S. (1986). Folk Music of Kenya. . Nairobi: Uzima Press. 